\title{
COMPANY TRAINING FROM THE EFFICIENCY AND EFFECTIVENESS POINT OF VIEW
}

\section{Dana Maria Staňková, Miloš Drdla}

\section{Abstract}

The paper concentrates on the topic of efficiency and effectiveness of company training. This work has set research goals that were solved using the interrogation method, questionnaire technique and free interview. Goal No. 1 was to investigate the situation in the company training from the motivation aspect and stimulating education system requirements. Goal No. 2 was to determine the use of educational methods, forms of training from the point of view of their efficiency. Goal No. 3 was to investigate into the attitude toward company training evaluation and exploitation of the individual levels of educational process efficiency evaluation. As a resource for the training efficiency evaluation the authors used Kirkpatrick's 4-level Learning Evaluation Model extended with the ROI method. The research group consisted of a) HR managers / managers from the SME sectors, $b$ ) participants of these companies' training programmes. The most important requirements for an efficient stimulating educational system involve the conformity with the needs and goals of the company, linking with the performance system and accord with the needs of an individual. The research has shown that in certain educational methods and forms there occurs conformity between the frequency of their usage in practice and apprehension of their efficiency, e.g. the controlled discussion method and the direct group education form. In others, such as the practical example method and individual consultation form, their usage in practice is minimal, but there is a high apprehension rate
Mendel University in Brno

stankov1@node.mendelu.cz

ARTICLE INFO

Article type

Full research paper

doi: 10.7160/eriesj.2012.050102

Article history

Received: October 31, 2011

Received in revised form: February 5, 2012

Accepted: February 23, 2012

Available on-line: March 31, 20112

of their efficiency. The efficiency evaluation is implemented mostly only on the 1st and 2nd level (the reaction level and learning level). However, in a responsible approach to the efficient use of financial means invested into the training process also a shift of evaluation on the $3^{\text {rd }}$ and $4^{\text {th }}$ level (transfer to the work-place level and business result level) and ROI are necessary.

\section{Key Words}

Company training, effectiveness, efficiency, responsibility, management, evaluation

Staňková, D. M., Drdla, M. (2012) "Company Training from the Efficiency and Effectiveness Point of View", Journal on Efficiency and Responsibility in Education and Science, Vol. 5, No. 1, pp. 10-24, ISSN 1803-1617, [on-line] www.eriesjournal.com/_papers/article_162.pdf [2012-03-31]. doi: 10.7160/eriesj.2012.050102 


\section{Introduction}

The effectiveness of a training process can be measured from several specific views and from its content. There are various theories and ways of classification according to different criteria. However, the most commonly used way is measuring the effectiveness in relation to an individual (i.e. course participant) and in relation to the organization ordering the course. Another one is measuring the pedagogical effectiveness (in which the area of objectives and results to be achieved by training is stressed) and measuring the economic effectiveness (the main focus being the field of financial and economic resources invested in the training and consequently its quantifiable benefit for the company). Training evaluation is defined as a systematic collection of information of descriptive and judgemental nature that is needed to produce effective decisions related to the selection, adoption, value, and modification of training intervention (Goldstein, 2002). Participant evaluations of tuition must to be reliable, valid, and accurate because they are often used for summarising evaluation decisions of high value about instructors, for example: promotion, tenure, and merit pay. These evaluations should therefore adequately assess the instruction efficiency and should not be biased by factors outside the control of the instructor. In general, participant evaluations of tuition are considered valid, reliable, and useful means for the evaluating of instructional effectiveness. (Marsh, Roche, 2000; Theall, Franklin, 2001). Some of these variables include content area, motivation of the participants, personality of the instructor, type of requirements demands put on the course, and method of presentation of the course. (Kelly, Ponton, Rovai, 2007). But evaluation has often been overlooked or not realised in its full extent. (Wang, Wilcox, 2006). One of the more common tools used often to evaluate training interventions is a survey (Bennett et al, 2003). Surveys can prove effective tools for data-capturing of potential results of training evaluation, such as acquired declarative knowledge, affective reactions of the participants, and their perceptions of the overall utility of the training. (Stoughton, 2011).

For the purpose of measuring the effectiveness and efficiency of the educational process within workplace training, it is possible to use many models which differ in their attitude to measuring the given effectiveness, one of them being The Workplace Training Evaluation (which includes the rules and techniques for measuring effectiveness of an educational process not only for teachers, but also for personnel officers and HR managers), the author of which is L. Rae (1999). The model of J. Sullivan (2008), defines five categories including several indicators. The categories are as follows: 1. „before the training ", 2. „at the end of the training", 3. "postponed influence (outside workplace)", 4. "the change in behaviour in workplace", 5. "the change in work performance in workplace". The DMADDI method (Define, Measure, Analyze, Design, Develop, Implement), published by K. A. Islam (2006) presents the maximization of business attitude to the creation of training programmes.

Kirkpatrick's Four Levels of Evaluation is among the most frequently used models for effectiveness assessment. This model, in which training is assessed regardless of its form, methods and techniques applied in education, although used for several decades, has well stood the test of time. According to this model, the whole process starts with the connection between business and training, when the basis of all training is the use of a market opportunity, solution of a business problem and the development of human capital in order to achieve company's goals. In 2009, the Kirpatrick's model was updated in relation to the preparation (analysis) before the actual start 
of the training process with the following change of procedure - the preparation stage starts from level 4th with a clear definition of success (link to level 4th) and subsequently key behaviour (i.e. specific behaviour supporting the achievement of previously set objectives) and factors of success (i.e. processes and activities done by others, such as software programmes, teachers, coaches, other training participants etc.) (link to level 3rd). The aim of these factors is to encourage course participants to implement the gained knowledge and skills. This is followed by paying attention to competences, i.e. required knowledge, skills and behaviour necessary for the implementation of newly gained knowledge and skills (link to level 2nd). In the last stage the focus is the conditions (participant's preparedness, company culture, motivating and stimulating programmes etc.) under which the training will be delivered (link to level 1st) (Kirkpatrick, J. D., Kirkpatrick, W. K., 2010). When the plan for all four levels is set, the actual preparation of the training programme able to meet all the objectives and to achieve the results in adequate quality can follow. In order to guarantee sufficient efficiency of the training process, it is important that the course designers (in cooperation with a person in charge of training in the company) establish the tools and methods for assessing and measuring all the four levels.

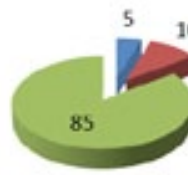

$$
\begin{aligned}
& =\text { Follow-Up } \\
& \text { = Pre-Work } \\
& =\text { Leaming Event }
\end{aligned}
$$
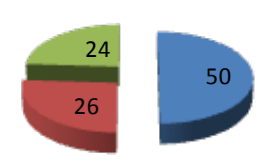

- Follow-Up

- Pre-Work

Figure 1: Typical Learning Investment (\%) Figure 2: Contribution to Learning Effectiveness (\%)
The Figure 1 and Figure 2 show a situation presented in training - the time spent by developing training programmes and activities related to them and, on the other hand, which activities actually contribute to learning effectiveness of a given training. The data was collected by Dr. Brent Peterson from Columbia University in 2004 (Kirkpatrick, 2006). Although they do not present Czech workplace training conditions, it is possible to find similarities with the situation in the Czech Republic. Most time is dedicated to designing the structure of the training, its preparation and subsequent delivery despite the fact that this part can ensure the required effectiveness only to a very limited degree. Insufficient time is dedicated to the area, which seems to be crucial in achieving effective results, i.e. the area of behaviour and results (level 3rd - transfer to the work-place level and level 4th - business results level).

In the training process managers of individual levels of management play an important role. At the beginning, managers in most companies identify partial or complex educational needs, based on e.g. regular appraisals (which are mostly done every 6 months and less often every 3 months or once a year), or on discovering a certain deficiency (e.g. worse proclient attitude, lower results of sales representatives etc.). This initial impulse to the need to run training comes either from the employees or their line managers. Afterwards, following the organization structure of a company, the suggestion goes through the approval process in which the final decision is usually made by the HR manager and personnel officer while assessing the needs, budget possibilities, as well as team and company goals and priorities for the given period.

The basic inputs for the identification of a deficiency, development needs and possibilities are individual needs (work performance and competence evaluation) and company needs 
(business strategies with their aims and ways of achieving them). An example of the subjective methods of development needs identification is autofeedback (with these varieties: continuous key decisions analysis, retrospective feedback), the objective methods of identification include development needs identification by a superior (ideally following the can - knows - can do - wants pattern), Development Centre, development plan or $360^{\circ}$ feedback. Benchmarking, Force Field Analysis and Development Centre are used for the purpose of company deficiencies and needs identification (Hroník, 2007).

Managerial work has certain characteristics, where directly related or related in a certain manner to the training are especially: Conflict of the objectives - the goals toward which the manager is heading in his direction tend to have a conflicting element in certain cases. The requirement of a maximum profit is not in accord with the requirement of an employee's maximum wage, at the same time the economic and educational objectives stand in opposition etc. The task of the manager is to find and ensure the balance of all objectives. Responsibility for the results - within the scope of his activities, the manager is not only responsible for the results of his work, but at the same time also for the results of work if his subordinates. It is necessary that he manages to find in time and at the same time promptly correct the errors in the process, or possibly eliminate their repetition in the future. He is responsible both for the success of the work entrusted to him and for the possible consequences of errors of his subordinates (Tureckiová, 2007). Working with a risk - the manager's work takes place in an uncertain and turbulent environment. The conditions of decision-making often change and what applied a short time ago need not necessarily apply now. The workload of situations that are unpredictable, and therefore cannot be included in the planning, always brings a certain part of the risk and uncertainty that the manager must hypothetically take into account and be ready for it, i.e. be able to adapt quickly and react flexibly. Working through other people - managerial work takes place in cooperation and through not only subordinates, but at the same time with equally or higher ranked colleagues, clients, suppliers etc. Success of the managerial work depends on the art of dealing with people, predict, create groundwork for decision-making and quality communication. This way the importance of teamwork significantly increases (Urban, 2003). Determination of employees' needs - knowledge of the employees' working objectives, their ambitions, sensitive work with the individual employees' personality types, determination of the individual needs related to their working rank and needs for training leading to an increase of their working competences. The true benefit not only to the individual, but also his company may be brought only by quality training. But how to define the quality of an educational product? Education has many different aspects, which can be evaluated and which at the same time have a different level of significance to their recipients (Müller, Myllyntaus, 2008). One of the many quality definitions says that both the creators and consumers of training and other services of an educational institution pronounce their ideas and expectations that should be fulfilled. If it is possible to prove in a suitably elected period of time that the expectations have been fulfilled, it is possible to speak about the achievement of quality adequate to it. The quality of education relates to the quality of the studies, to the quality of the whole educational process (Witzany, 2002).

Reaction measures and training motivation are the two areas that need to be further developed and researched. (Alvarez, Salas, 2004). Motivation has unsubstitutable influence upon the 
efficiency of the implemented company training and upon the preferred ways of tuition.

\begin{tabular}{|c|c|c|}
\hline $\begin{array}{c}\text { Type } \\
\text { of motivation } \\
\text { to learning }\end{array}$ & Contents & $\begin{array}{c}\text { Preferred kind } \\
\text { of learning }\end{array}$ \\
\hline $\begin{array}{c}\text { Cognitive } \\
\text { motivation }\end{array}$ & Learning new knowledge. & $\begin{array}{c}\text { Concentration on new } \\
\text { information, news. }\end{array}$ \\
\hline $\begin{array}{c}\text { Adaptation } \\
\text { motivation }\end{array}$ & $\begin{array}{c}\text { Being part of a certain } \\
\text { group, cope with } \\
\text { expectations set onto the } \\
\text { given role by others. }\end{array}$ & $\begin{array}{c}\text { Group learning, } \\
\text { team collaboration } \\
\text { with reception and } \\
\text { confirmation of } \\
\text { participants. }\end{array}$ \\
\hline $\begin{array}{c}\text { Motivation to } \\
\text { assert oneself }\end{array}$ & $\begin{array}{c}\text { Reaching a distinction, } \\
\text { respect and performance } \\
\text { deserving admiration. }\end{array}$ & $\begin{array}{c}\text { Practice courses, } \\
\text { contests, anything } \\
\text { increasing } \\
\text { effectiveness. }\end{array}$ \\
\hline $\begin{array}{c}\text { Motivation } \\
\text { through } \\
\text { self-affirmation }\end{array}$ & $\begin{array}{c}\text { Discovery, specification } \\
\text { of self-apprehension, self- } \\
\text { acceptance and realization } \\
\text { of one's capacities. }\end{array}$ & $\begin{array}{c}\text { "Experience" and self- } \\
\text { examination courses. } \\
\text { Inter-connection } \\
\text { of professional } \\
\text { and personal } \\
\text { development. }\end{array}$ \\
\hline motivation & $\begin{array}{c}\text { Realization of } \\
\text { impersonal motivation and } \\
\text { knowing "why". }\end{array}$ & $\begin{array}{c}\text { Need to inter-connect } \\
\text { the personal and } \\
\text { corporate visions, } \\
\text { learning in context. }\end{array}$ \\
\hline
\end{tabular}

Table 1: Relation between motivation to learning and preferred ways of learning (Hroník, 2007)

\section{Material and Methods}

For the purposes of this research investigation, also the area of soft skills and hard skills was included in the research study. Within the scope of the questionnaire and consequently implemented interviews, the state of efficiency evaluation on the platform of Kirkpatrick's 4-level model was determined.

\begin{tabular}{|c|c|}
\hline $\begin{array}{l}\text { Level } 4 \text { - } \\
\text { RESULTS }\end{array}$ & $\begin{array}{l}\text { Key Question: Did the participant achieve the desired } \\
\text { outcomes of the programme of learning? } \\
\text { Data Sources: participants/employer/advisor surveys, } \\
\text { focus groups, interview, previous data, concrete indicators. } \\
\text { Timing: Usually done } 3 \text { months - } 2 \text { years after learning } \\
\text { experience. }\end{array}$ \\
\hline $\begin{array}{c}\text { Level } 3 \text { - } \\
\text { BEHAVIOUR }\end{array}$ & $\begin{array}{l}\text { Key Question: Are the newly acquired skills, knowledge, } \\
\text { or attitude being used by the learner after learning event } \\
\text { is completed? } \\
\text { Data Sources: Level } 2 \text { re-assessment, participants/employer/ } \\
\text { advisor surveys, focus groups, interview, previous data. } \\
\text { Timing: Usually done } 1 \text { month - } 3 \text { months after learning. }\end{array}$ \\
\hline $\begin{array}{c}\text { Level } 2 \text { - } \\
\text { LEARNING }\end{array}$ & $\begin{array}{l}\text { Key Question: Did the participant achieve the desired } \\
\text { learning objective(s)? } \\
\text { Data Sources: tests, assignments, discussions } \\
\text { Timing: Usually done immediately or soon after learning. }\end{array}$ \\
\hline $\begin{array}{l}\text { Level } 1 \text { - } \\
\text { REACTION }\end{array}$ & $\begin{array}{l}\text { Key Question: What was the participant reaction to the } \\
\text { learning environment? } \\
\text { Data Sources: participant surveys, focus groups, interviews, } \\
\text { previous data. } \\
\text { Timing: Usually done immediately or soon after the } \\
\text { learning event(s). }\end{array}$ \\
\hline
\end{tabular}

Due to the fact that the aforementioned model does not evaluate the financial assets gained from the implemented training, this "weakness" was removed by J. J. Philips by adding the 5th level, 
on which the ROI (Return of Investment) method is applied, while the efficiency is evaluated on this level from the economic point-of-view. ROI $=((\text { Total earnings }- \text { Costs }) / \text { Costs })^{*} 100$ (Chapmann, 2009).

\section{Objective and methodology of Part One of the research, characteristics of the research group and specifications of its selection}

Objective No. 1 was to determine the situation in the company training from the point of view of motivation and requirements put on the stimulating educational system.

After obtaining the primary data for the purposes of this research investigation, the interrogation method was chosen the self-constructed questionnaire technique using closed and semi-closed questions. To obtain further primary data, the free interview technique was used. The reason for the choosing of this exploration technique was the complementation of the necessary information to the problem under research.

The companies were chosen for the basic group from the accessible database of 890 organizations (SME) operating in the territory of the Czech Republic, creating a set of 296 organizations (including, according to the company category, 176 medium-sized, 120 small) through a systematic random selection. Questionnaires were sent to the chosen companies, while 157 filled-in questionnaires were returned. The return rate therefore amounted to 53\%. During the processing it was necessary to discard 6 questionnaires due to their being incomplete. Therefore a total of 151 (SME: 87 medium-sized, 64 small) filled-in questionnaires were included in the research investigation. The collection of empirical data, continuous analysis and subsequent evaluation of the findings was implemented from 6/2011 to 10/2011.
The research group consisted (one respondent for each company, questionnaire - part I.) of 151 respondents, these being either personnel officers or HR managers or managers on the middle and higher level of company management from the SME (small and medium-sized companies) sector.

\section{Objective and methodology of Part Two of the research, characteristics of the research group and specifications of its selection}

Objective No. 2 was to determine the use of educational methods, forms of education from the point of their efficiency in company training.

To obtain primary data for the purposes of this research investigation, the interrogation method was chosen - the selfconstructed questionnaire technique using closed and semiclosed questions, further also the free interview technique.

Data for the topic of educational methods representation were obtained from the personnel clerks or HR managers of the given companies.

Data for the topic of perception of the educational methods and forms in companies were obtained always from two persons in each company. One was a "superior" and the other a participant of the training (questionnaire - part II.). In the "superior" set there featured both direct superiors of the training participants, i.e. managers on all management levels, but also HR managers and personnel clerks, if the participant was a top manager. The reason why only HR managers and personnel clerks were not chosen, but other managers as well, was that the efficiency and effectiveness of the realized training can only be maximally perceived from the point of a direct superior of the training 
participant as he has the possibility to evaluate the impact "at close range" and in an everyday contact.

The sets prevented the cross effect or duplicity in responses upon the given topic from different positions (categories) by eliminating the respondent, if he ticked the "Participant" category, not being able to respond in the "Superior" category.

The research group consisted of 151 personnel clerks, HR managers and managers on the middle and higher management level of the companies and 151 training participants. The process of questionnaire distribution, their return rate, empirical data collection schedule, analyses and subsequent evaluation is equal to the 1st part of the research.

\section{Objective and methodology of Part Three of the research, characteristics of the research group and specifications of its selection}

Objective No. 3 was to determine the attitude toward the evaluation of company training in companies and the usage of the individual levels of evaluation of the educational process efficiency.

To obtain primary data for the purposes of this research investigation, the interrogation method was chosen - the selfconstructed questionnaire technique using closed and semiclosed questions, further also the free interview technique.

The research group was equal to that from the first part of the research. The process of questionnaire distribution, their return rate, empirical data collection schedule, analyses and subsequent evaluation is equal to the 1st part of the research.

\section{Results}

The companies that prove a sufficient level of responsibility and approach education as an investment for the given company, but also for the individual, have incorporated a system in their practice, which is immediately of significantly influence the individuals' attitude toward education and its subsequent maximum use for the company in accord with the company strategy. The importance of the requirements that should be considered in the creation of an efficient stimulating training system is the following (Figure 3): the accord with the needs and objectives of the company (stated by $94 \%$ of the respondents), further it is the correlation with the performance system (89\%) and accord with the needs of an individual (82\%). Smaller importance is predicated to a permanent experience exchange and knowledge among managers on the leading positions and key employees (76\%), then to the provision of training to only a "selected group" of individuals (68\%), which ensures its higher efficiency (i.e. not on an overall basis), and its adaptation to the capacities of the company (57\%) and the individual (52\%).

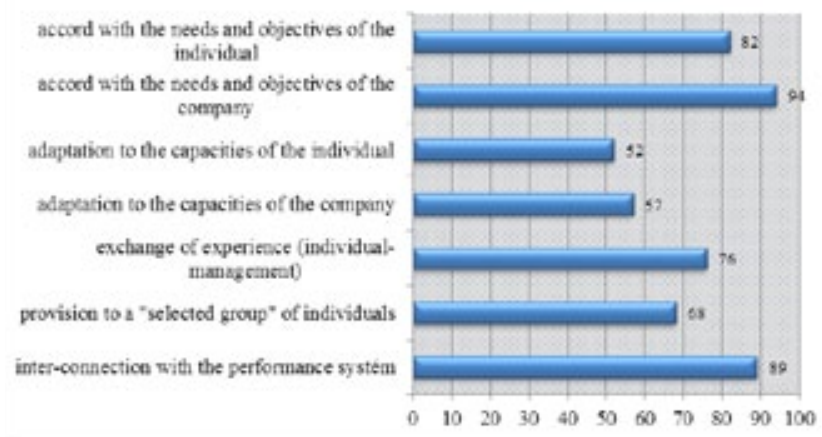

Figure 3: Requirements for the stimulating education system in companies $(\%)$ 
The following Figure 4 shows a survey of representation and usage of educational methods within the scope of internal company training.

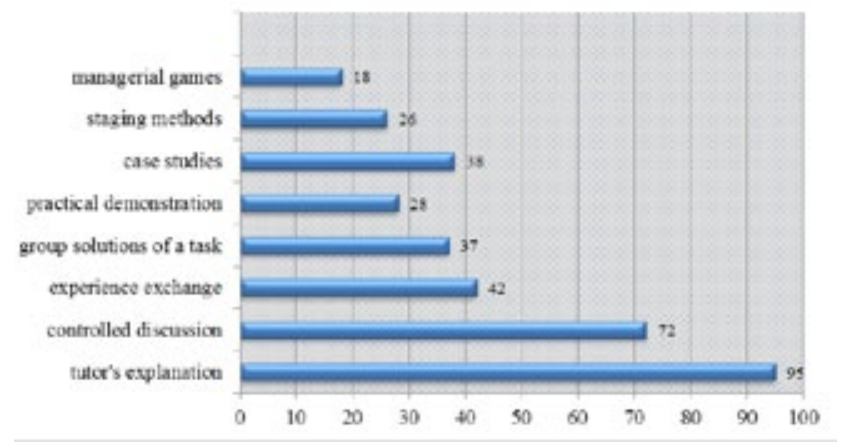

Figure 4: Representation of educational methods in company training (\%)

To increase training efficiency and subsequent maximum use in its implementation in practice, various methods are used, which are applied in specific combinations within the scope of individual training seminars, modules etc. Their combination is determined not only by the choice of the lecturer of the relevant training, but also by the essence of the given training. That means: if it is a lecture, seminar, workshop, training etc.

The tutor's explanation is one of the most frequently used training methods (stated $95 \%$ of the respondents). It concerns mainly to the theoretical commentary of the lecturer with respect to the genesis of development and knowledge in the relevant area, supported by scientific findings and experience with the application in other organizations of similar orientation. Another very often used method in company training is a controlled discussion $(72 \%)$, i.e. mutual exchange of knowledge and opinions on a solution of problems according to the recommended methodology under the lecturer's tuition. Exchange of experience (42\%) among the participantsparticipants and participants-lecturer take place especially with the aid of brainstorming and exchange of experience with its results. In group solutions of a task (37\%) the participants in smaller groups solve tasks, which are subsequently presented and feedback is mutually exchanged among the groups, which is complemented with the lecturer's experience. The practical demonstration $(28 \%)$ uses a presentation of the application of theoretical findings in practice with the citation of pros and cons, both in the course of implementation and in the full functionality of the given methodology. Within the scope of case studies (which are used in the practice of the company training in $38 \%$ ) specific problems are solved by the participants using the presented methodology and theory discussed. Participants of the training are involved in the whole evaluation, give each other feedback and together they formulate the optimum solution. The lecturer functions in the role of an anchorman, at the same time providing feedback in the course of the session and then at its very end. Other interactive methods used within the scope of the company education are staging methods $(26 \%)$, in which the participants play roles in defined topics and the attitude and approach to the topics of the individual participants are then evaluated in the groups and at the same time their learning ability is evaluated, and furthermore there are management games $(18 \%)$ where the participants get involved in the pre-defined situations and take up fictitious managerial roles and responding responsibilities.

The data of the following figure will get us acquainted with the way the individual educational methods are perceived from 
the point of their effectiveness, both from the perspective of the training participants and of the direct superiors of the training participants (in case of a participant - top manager then from the point of view of the company's HR manager).

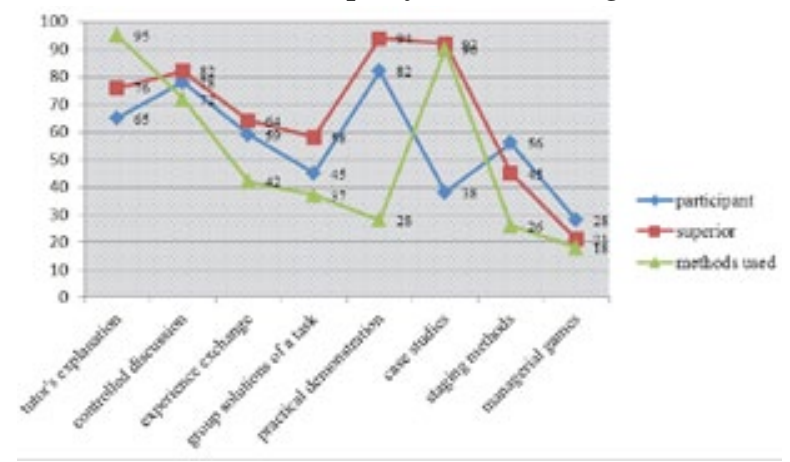

Figure 5: Efficiency of educational methods in company training (\%)

As the Figure 5 shows, the participants consider the case study (92\%) the most efficient educational method, then to an almost equal extent the practical demonstration ( $82 \%)$ and the controlled discussion $(78 \%)$. In the practical demonstration and case study we can see a significant imbalance in the minimal usage of these educational methods in training (in the practical demonstration $28 \%$ and in the case study $38 \%$ ) in relation toward their efficiency rate, which is awarded to them by the training participants as well as their superiors (in the practical demonstration $94 \%$, in the case study 90\%). The apprehension of efficiency in the individual educational methods is in a relative accord between the training participants and their superiors. Management games were seen as less efficient methods (participants: $28 \%$, superiors: $21 \%$ ). The experience exchange (participants: $59 \%$, superiors: $64 \%$ ), staging methods (participants: $56 \%$, superiors:
$45 \%$ ) and group solutions of a task (participants: $45 \%$, superiors: $58 \%$ ) ended up on the middle level.

From the point of company training, it is also interesting to see the comparison of the most often educational forms as well as the evaluation of their efficiency by the training participants and direct superiors of these participants, or by HR managers (Figure 6). Most often represented, with the whole $100 \%$, is the direct group tuition, it means that in the companies of all investigated respondents this form of education is being realised. At the same time, it efficiency rate is seen very high by both the participants (where $91 \%$ respondents put is as highly effective) and the superiors (95\% respondents). The second most often used form is the direct group consultations (40\%), the efficiency of which is indicated by $65 \%$ of the participants and $71 \%$ of the superiors. E-learning is used in company training only in $22 \%$, and its efficiency is seen on a rather low level, i.e. by $15 \%$ of the training participants and $10 \%$ of their superiors. A significant disproportion can be recorded in the direct individual consultation (used in 15\%, but its efficiency is appreciated by $95 \%$ of the participants and $89 \%$ superiors), and the electronic individual consultation (used by $10 \%$, efficiency in participants $74 \%$, in superiors $65 \%$ ). 


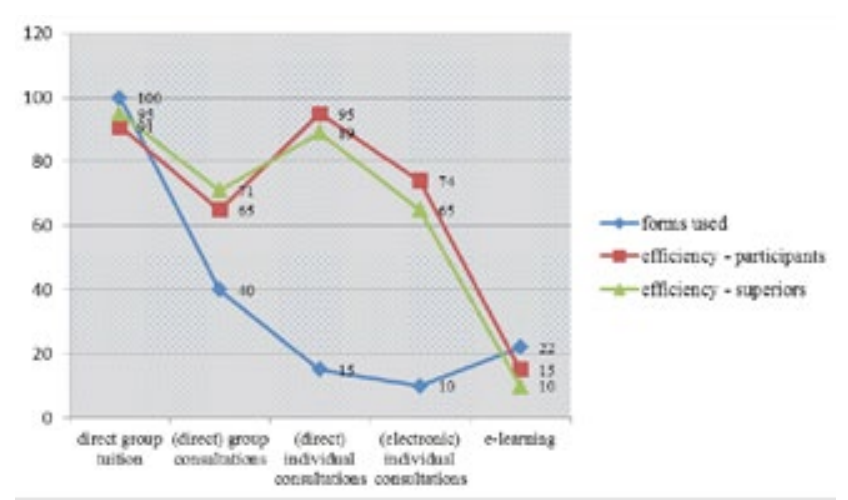

Figure 6: Education forms their efficiency evaluation used (\%)

In another figure (Figure 7) there are results recorded from the area of approach and attitude in the companies toward the evaluation of the education realised. In a majority of the companies, the training evaluation is carried out. But it is only on the 1 st level, i.e. reaction $(71 \%)$, less so on the 2 nd level learning $(32 \%)$. Minimal attention is paid to the 3rd level behaviour $(10 \%)$ and 4 th level - results $(7 \%)$. Only in $5 \%$ the financial benefits are compared with the costs invested, i.e. ROI (Return of Investment). The evaluation in carried out in 9\% of the companies and in $20 \%$ of the companies not, but they are considering introducing the training events evaluation.

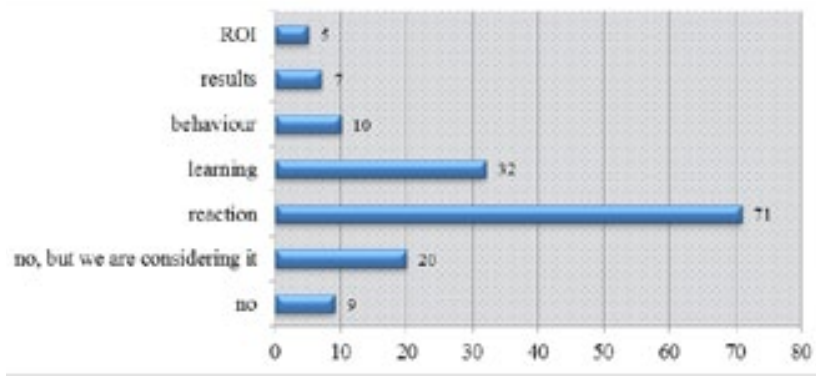

Figure 7: Attitudes toward evaluation of training in companies (\%)

\section{Discussion}

To secure the efficiency of the company training it is necessary to implement important requirements in the stimulating training system, which will be especially the accord with the needs and objectives of the company, inter-connection with the performance system and accord with the needs of an individual. Training fulfils also its unsubstitutable function in the motivation area. However it requires a sensitive attitude of the HR manager or manager of the individual teams in the sense of sufficient communication and clarification of the reasons for the implementation of a long-term educational programme, project or short-term courses, and the expected benefits both for the company, team/department, and the individual as such. In this point there dwells the essential meaning which influences not only how actively or passively an individual will approach the training, but also how the newly acquired knowledge will subsequently applied in practice, i.e. the exploitability rate of the investment into the training in the direct operation of the company. If an individual correctly understands the significance and justness of the education, he will adopt an attitude toward 
the educational process with a necessary and desirable level of self-motivation.

In the companies where training is approached systematically and strategically (i.e. in accord and with the aim to reach the marked objectives on the level of functional strategies issuing from the corporate strategy), the training is perceived by the individuals as a means for the reaching of their goals, development of abilities, professional growth and improvement of working performance. Therefore, his feeling of solidarity is supported, as well as the feeling of importance within the company, his loyalty is incited and his highest need of selfrealization satisfied (Maslow's hierarchy of needs, Maslow 2011). According to Drucker (2008) only a company, which follows the way of increasing innovation and productivity of all its key resources, is capable of succeeding in the hard competitive environment. And it is exactly the educated, efficient and capable who are motivated, but mainly selfmotivated, to identify their goals with the corporate goals play a decisive role in every company. Therefore it is highly important to set the company motivation policy correctly and use suitably educational means for the sustenance and development of the human potential. An obvious necessity is, especially in key employees, the sufficient knowledge of their capacities, abilities, ambition, means for the fulfilling of their self-realization and talent development. This is ensured e.g. by means of the regular evaluation interviews, providing feedback etc. Within the scope of the research investigation there resulted from the interviews that some companies use sophisticated metrics and investigation with which they are able to identify the objective state of working satisfaction, motivation and loyalty of their employees. That is e.g. the TRI*M TM system the results of which can be: TRI*M index (satisfaction and motivation rate),
TRI $^{*} \mathrm{M}$ grid (analysis of strengths and weaknesses) and TRI*M typology (classification of employees). Satisfied and motivated employees represent an essential element for the satisfaction and loyalty of customers, and those represent the potential for the acceleration of revenues and profit of the company.

Within the scope of the results of the partial outputs of the research investigation we could get acquainted with the perception of efficiency of the individual educational methods that are used in company training, and at the same time also with the perception of efficiency of the educational forms. Within the scope of the realized interviews, there resulted what was in fact perceived as "efficient" by the individual participants and their superiors. That means especially a clear impact of the newly acquired knowledge and skills on the participants' practice providing that certain types of training (especially in the soft skills area) era expected to be almost immediately reflected in the change of attitude, behaviour, ways of communication etc., in certain types of training (especially in the hard skills area) it is accepted that efficiency of the training manifests itself only with a certain time gap. Another efficiency criterion stated was: contents of training in accord with the participants' needs; correctly chosen methods and forms ensuring a maximum absorption of the training supplied; active attitude and mutual interaction between the participants and the tutor as well as among the participants. Through the questionnaire research it was verified that in some training methods and forms there occurs conformity between the occurrence of their usage in practice and perception of their efficiency (" + " controlled discussion ((i.e. high amount of application in practice and high apprehension of efficiency)), "-" management games ((i.e. low amount of practice and low apprehension of efficiency)); "+" direct group training, "-" e-learning). Misbalance, on the 
contrary, occurred in the case of the practical demonstration method and case study and the form of direct individual consultation and electronic individual consultation, which are used in practice to a lower scale, but the rate of their efficiency perception is relatively high.

The attitude toward evaluation clearly shows that after the implementation of a company training the competent persons responsible for education, i.e. mainly HR managers of personnel clerks, realise mostly evaluation on the 1st and 2nd level of Kirkpatrick's model. On the 1st level (stated $71 \%$ of respondents) there is the realization of the reaction, response of the participants to the training obtained, their satisfaction with the education. It is carried out immediately after the completion of the training, either by the lecturers themselves, who pass the evaluation over (often with their own comments) to the persons in the company who are responsible for education. at the same time, this record serves for the evaluation of the lecturer's performance in the objective seminar, relevance of the contents, validity of the chosen methods and forms of tuition, tempo etc., both for himself and for the training institution where he is a member of the lecturing staff. The filled in questionnaires further serve both for the needs of the commissioner on different management levels in relation toward the participants and for the needs of the supplier for a possible modification of the training and securing of maximum quality of the services provided. Sometimes the setting of a so-called consultation system is used in practice, in which there occur possible modifications of the training content structure in the course of the project, namely on the basis of a prompt evaluation of feedback in the form of the aforementioned questionnaires. Criteria are acquired from this 1st evaluation level (reaction level), which are e.g.: relevance, contribution, professional attractiveness etc. On this evaluation level, however, the company receives, said in a simplified manner, only the information if the participants liked the given training and how much, but not with respect to its efficiency. But the justness of the evaluation of the 1st level dwells on the acquisition of feedback for the following measures in the relation to an increase of the training programme's quality.

On the 2nd level of Kirkpatrick's model (learning level) the evaluation is realised in $32 \%$ of the respondents. It concerns to the verification of the extent to which the training participants gained the necessary and expected knowledge and skills, or possibly attitudes thanks to the participation in the given training. This evaluation takes place in the cooperation of the persons with the training participants' direct superior who is capable of determine and define what is the key knowledge and skills important ant in relation to the team and corporate objective. As results from the realised interviews, the evaluation of the rate and scope of the knowledge and skills acquired takes place by way of tests and quizzes. In a smaller extent then, individual or group presentation of the problem solved is presented, or a demonstration of conduct (e.g. communication with a customer, sales skills etc.). The evaluation may take place both on the formal level, informative on the lecturer's side; there are also (in fact to a minimal extent) used form of selfevaluation and group or team evaluation. In practice the usage of a form of not only the single shot test became useful, but also variants of a "pre-test and re-test", when the identification of knowledge is effectuated at the beginning of the course and then in approximately $3-7$ days (to measure long-term memory). The tests (occupations, specific, professional, didactic etc.) tend to be written, but according to preferences of the commissioner, tests in electronic form are also used. 
On the next level, i.e. 3rd - (behaviour, transfer to the workplace level) there already occurs evaluation of the effect of the training, i.e. what values and specific real results were reached in the company by the implementation. Yet this effectiveness and efficiency evaluation level is only used in practice by only $10 \%$ of the respondents. But it is a fundamental area in which the evaluation concerns to what new work habits have been reached, in what way the working competence of the training participant has increased, to what extent the contents of the training are used, how the changes are demonstrated directly in the workplace. As shown in the performed research, by means of the interview technique, the companies who implement this evaluation level use especially the focus groups technique (goaloriented discussion groups), individual structured interviews and observations. Another applied technique, but only to a minimal extent, is the behavioural interview.

Although the 4th level of evaluation is very important in relation to the detection of the true effect of the educational process on the company from the point of increase of results or e.g. improvement of organizational processes, this evaluation is brought into effect only in a narrow number of cases $(7 \%)$. Nevertheless, it is here where the companies can ascertain whether the training, which the y organised for their management or staff, brought the necessary productivity, efficiency and therefore also a higher profit rate. The companies that carry out the evaluation on this 4th level gain two basic categories of data - hard data (which is for instance a number of sold products, services, number of products manufactured, time necessary to produce a certain component, etc.) and at the same time soft data (internal company communication of higher quality, decrease of absence rate, increase of loyalty, etc.)
ROI - Return of Investment is evaluated only in v $5 \%$. This number is alarming, especially at the time when must companies, due to the impact of the economic recession, still very sensitively select into what, why and with what objectives and expectations their financial means will be invested. In the Czech practice the ROI method has not found its place yet and the companies are mostly satisfied with a "mere" fillingin of questionnaires after the termination of the event, which is something little demanding of time and energy. The reason can be, rather than a certain amount of conservatism, the way of financial resources. Due to a high support of education in the EU, the companies have a possibility to draw financial means from the European social fund by way of subsidy from the individual operational programmes (Human resources and employment OP, Education for competitiveness OP etc.). Within the scope of the monitoring reports requirements therefore only questionnaires are filled in involving satisfaction with the training, its contents, instructor's presentation, enrichment with new knowledge etc. From the financial point of view, for the purposes of the monitoring reports, the approved amounts spent in the individual sections are observed, not the return of investment. And due to the fact that these means are not spent by the company directly, it is not possible to expect a higher initiative in relation to the evaluation of return of investment in education.

From the point of view of the training programme efficiency, it is possible to see also the advantages and disadvantages resting in the composition of the group, i.e. if it is a homogenous or heterogeneous composition of participants from the point of view of their ranking and management level. In the homogenous composition, the advantages are seen in the fact that the group knows its own problems and therefore it is capable of going 
into detail in the given area; further, that the group is capable of a "quality" communication - when the fact that they are on an equal ranking level is a prediction operator for the willingness to share more openly and communicate the given problem. The disadvantage then dwells in the single-sided view of things. If the training takes place in a heterogeneous group of participants, advantages can be seen in the sharing of experience and view of the given problem from different angles; furthermore, that the prediction of "learning" the quality cooperation and understanding of specific problems of "the other party". The disadvantages dwell in the fact that the participants sometimes are not "able" and willing to communicate and discuss openly.

\section{Conclusion}

The presented paper solves a problem of effectiveness and efficiency of training in companies. The research has shown what important elements can be used in the motivating and stimulating programmes to increase the training efficiency, furthermore also the perception of effectiveness of the individual training methods and forms of education in comparison with their application in practice, and also what the situation is regarding the evaluation of training efficiency in companies. One of the basic company tasks is the valorisation of the entrusted property and creation of conditions for the return of investment. The return of investment is also one of the key characteristics of the economic behaviour of the organization. Employee training is always an investment from the company's point of view. It is an investment of time and consequently always a financial investment too. This investment must have its return rate and efficiency. The responsibility of companies rests in an efficient treatment of financial means invested into the educational process. Therefore it shows indispensable that the practice in companies when only the first two levels are evaluated (i.e. the reaction level and learning level) moved two levels higher and the transfer to the work-place level, business result level and ROI were evaluated too. The measuring of the return of investment and efficiency of training is therefore not only useful, but it is also a direct prerequisite. It is a prerequisite of creation of training plans, conceiving of educational strategies or composition of specific educational programmes. Through education it is possible to gain a number of benefits, the most significant ones involving a higher performance rate, productivity and competences of the employee, more efficient team work, adaptability and readiness of the company for changes, improvement of the internal company communication, increase of competitiveness through a more effective involvement of the employees, quality relations with customers/clients and a more efficient reaching of goals set by the company strategy. If the training is approached with regard to the needs of the individuals and the company at the same time, it is a significant motivating and indispensable tool in the human resources management in accordance with the set company objectives of both short-term and long-term nature.

\section{References}

Alvarez, K. and Salas, E. and Garofano, Ch. M. (2004) "An Integrated Model of Training Evaluation and Effectiveness", Human Resources Development Review, Vol. 3, pp. 358-416

Bennett, W. et al. (2003) "Expanding the training evaluation criterion space", Military Psychology, Vol. 15, No. 1, pp. 59-76.

Chapmann, A. (2009) “Kirpatrick's Training Evaluation Model - the Four Levels of Learning Evaluation", [online], http://www. businessballs.com/kirkpatricklearningevaluationmodel.htm. 
Drucker, P. F. (2008) The Essential Drucker: The Best of Sixty Years of Peter Drucker's Essential Writings of Management, HarperCollins Publishers, New York, 368 p.

Goldstein, I. and Ford, J. (2002) Training in organizations (4nd ed.), Wandsworth, Belmont, $432 \mathrm{p}$.

Hroník, F. (2007) Rozvoj a vzdělávání pracovníků, Grada Publishing, Praha, 240 p.

Islam, K. A. (2006) Developing and Measuring Training the Six Sigma Way, Pfeiffer, San Francisco, 256 p.

Kelly, H. F. and Ponton, M. K. and Rovai, A. P. (2007) "A comparasion of student evaluations of teaching between online and face-to-face courses", The Internet and Higher Education, Vol. 10, No. 2, pp. 89-101

Kirkpatrick, D. L. and Kirkpatrick, J. D. (2006) Transfering Learning to Behaviour: Using the Four Levels to Improve Performance, Berrett-Koehler Publ., San Fransico, 182 p.

Kirkpatrick, J. D. and Kirkpatrick, W. K. (2010) Training on Trial: How Workplace Learning Must Reinvent Itself by Remain Relevant, AMACOM, New York, 256 p.

Marsh, H. W. and Roche, L. A. (2000) "Effects of grading leniency and low workload on students' evaluations of teaching: Popular myth, bias, validity, or innocent bystanders?", Journal of Educational Psychology, Vol. 92. No. 1, pp. 202-228.

Maslow, A. H. (2011) Hierarchy of Needs: A Theory of Human Motivation, www.all-about-psychology.com, Kindle eBook.

Müller, M. and Myllyntaus, T. (eds.) (2008) Globalisation, management education and management practice. Pathbreakers. Wien, pp. 477-504.

Rae, L. (1999) Using Evaluation in Training and Development, Kogan Page, London, 240 p.
Sullivan, J. (2008) "Measuring Training Effectiveness/Impact", [online], http://ourworld.compuserve.com/homepages/gately/ pp15js18.htm

Stoughton J. W. et al. (2011) "Measurement invariance in training evaluation: Old question, new context", Computers in Human Behaviour, Vol. 27, No. 5, pp. 2005-2010.

Theall, M. and Franklin, J. (2001) "Looking for bias in all the wrong places: A search for truth or a witch hunt in student ratings of instructions", New directions for institutional research, No. 109, Jossey-Bass, San Fransisco, pp. 45-56.

Tureckiová, M. (2007) Klíč k účinnému vedení lidí, Grada Publishing, Praha, 128 p.

Urban, J. (2003) Řízení lidí v organizaci, ASPI Publishing, Praha, $189 \mathrm{p}$.

Wang, G. G. and Wilcox, D. (2006) "Training Evaluation: Knowing More Than Is Practiced", Advances in Developing Human Resources, Vol. 8, No. 4, pp. 528-59.

Witzany, J. (2002) "Př́spěvek k diskusi o kvalitě studia", Česká konference rektorů, 2002 [on-line], http: //crc.muni.cz/ documents/witzany.html.

Wolf, P., Hill, A., and Evers, F. (2006) Handbook for curriculum assessment. Guelph, Ontario, Canada: University of Guelpho. $24 \mathrm{p}$. 